\title{
Mutação ou Transmutação Constitucional, o tendencionismo à opinião pública como obstáculo aos Direitos Fundamentais
}

\author{
Constitutional Mutation or Transmutation, tendentionism to \\ public opinion as obstacles to Fundamental Rights
}

\author{
Vinício Carrilho Martinez ${ }^{l}$
}

Vinícius Alves Scherch ${ }^{2}$

\begin{abstract}
RESUMO
No contexto do pós-2016, a opinião pública toma o contorno regressivo e rompe com a democracia, se imponto e comprometendo a exequibilidade da Constituição enquanto uma Carta Política. Neste cenário, embora detenha a força interpretativa para viabilizar a adequação dos conceitos abertos da Constituição à realidade, o Supremo Tribunal Federal se desvia do papel contramajoritário, atraído pelo magnetismo social da maioria, operar em transmutação constitucional. A mutação, enquanto vinculada a ampliação dos direitos fundamentais, visa garantir o pluralismo, a transmutação, seu revés, elimina do catálogo de direitos qualquer possibilidade de ganho social que possa advir da interpretação, desconstruindo os objetivos constitucionais e colocando em extinção a pluralidade. Por meio de uma metodologia dedutiva e da pesquisa bibliográfica, chega-se ao intento que apresenta a tendência fascista e afeiçoada às exigências de mercado, aprisionando as tentativas de interpretação que visam garantir direitos fundamentais.
\end{abstract}

\footnotetext{
${ }^{1}$ Professor Associado II (Dr.) do Departamento de Educação da Universidade Federal de São Carlos. Pós-Doutor em Ciência Política e em Educação - UNESP/Marília. Possui graduação em Direito (1988) e em Ciências Sociais pela Universidade Estadual Paulista Júlio de Mesquita Filho - UNESP (1989); mestrado em Programa de PósGraduação em Direito pela Faculdade Estadual de Direito do Norte Pioneiro (2005); mestrado em Educação pela Universidade Estadual Paulista Júlio de Mesquita Filho (1996); doutorado em Educação pela Universidade de São Paulo - FEUSP (2001) e doutorado em Ciências Sociais pela Universidade Estadual Paulista Júlio de Mesquita Filho, UNESP-Marília (2010); Pós-Doutorado em Educação, desenvolvido junto ao Departamento de Administração e Supervisão Escolar da UNESP, Campus de Marília; Pós-doutorado em Ciências Sociais pela Universidade Estadual Paulista/Marília . Atualmente é Professor da Universidade Federal de São Carlos - UFSCar; Coordenou MBA em Direito. Foi bolsista de agências financiadoras de pesquisa, por quatro vezes consecutivas. Também foi professor colaborador do programa de Pós-graduação em Ciências Sociais - UNESP/Marília (20052006) e professor de programa de mestrado em direito. Tem experiência na área de Educação, ensino de Sociologia Geral e Teorias do Estado, com ênfase em Educação - Sociedade - Estado, atuando principalmente nos seguintes temas: Sociologia Geral, direitos humanos, Educação e Sociedade, Ciências Políticas e Teorias do Estado. Publicou livros, capítulos de livros e inúmeros artigos de caráter científico, nacionais e internacionais. É articulista de jornal regional há 15 anos, com aproximadamente 700 artigos publicados, e também tem uma página pessoal no site Jus Navigandi, referenciado com qualis B-3.

2 Mestre em Ciência Jurídica pela Univrsidade Estadual do Norte do Paraná - UENP (2019). Especialista em Administração Pública pela Unicesumar (2014), em Direito e processo do Trabalho pela Unopar (2015) e em Direito Constitucional Contemporâneo pelo IDCC (2018). Graduado em Gestão Pública pela Unopar (2015) e em Direito pela Faculdade Cristo Rei (2010). Integrante do grupo de pesquisa da Academia Brasileira de Direito Constitucional (2017), Intervenção do Estado na vida das pessoas INTERVEPES (2017), Democracia e Direitos Fundamentais (2018). Tem experiência na área de Direito, com ênfase em Direito Público, atuando principalmente nos seguintes temas: direito à moradia, direito orçamentário, direitos fundamentais, constituição e decisões políticas.
} 


\title{
PALAVRAS-CHAVE:
}

Direitos fundamentais; Hermenêutica constitucional; Mutação e transmutação constitucional; Realismo político.

\begin{abstract}
In the context of post-2016, public opinion takes the regressive outline and breaks with democracy, imposing itself and compromising the feasibility of the Constitution as a Political Charter. In this scenario, although it has the interpretive force to enable the adequacy of the Constitution's open concepts to reality, the Federal Supreme Court deviates from the countermajorital role, attracted by the social magnetism of the majority, to operate in constitutional transmutation. Mutation, while linked to the expansion of fundamental rights, aims to guarantee pluralism, transmutation, its reversal, eliminates from the catalog of rights any possibility of social gain that may arise from interpretation, deconstructing constitutional objectives and endangering plurality. Through a deductive methodology and bibliographic research, one arrives at the attempt to present the fascist tendency and fond of market demands, imprisoning attempts at interpretation aimed at guaranteeing fundamental rights.
\end{abstract}

\section{KEYWORDS:}

Fundamental rights; Constitutional hermeneutics; Constitutional mutation and transmutation; Political realism.

\section{INTRODUÇÃO}

O papel contramajoritário da Corte Maior é garantido por diversas formas de exercício do poder em defesa das minorias, da pluralidade e da democracia. Daí ser inevitável um choque entre a opinião pública e a proteção aos direitos individuais e fundamentais; a não ser que se siga o caminho do que aqui chamamos de Magnetismo Social - quando, em suma, o legislador ou o julgador corrobora um eco social ou, no dito popular, conforma-se diante da "voz rouca das ruas" em seu maior senso comum. Uma questão inicial, que se deve avaliar mais à frente, traz outro dilema:

- O julgador, ao seguir pelo Magnetismo Social e acobertado por longas citações de estrangeirismo, ao ser a contra face do senso comum, relega a cientificidade 
do direito (que se emprega nas citações) e a postula diante das ideologias e axiomas do senso comum ${ }^{3}$ ?

A Constituição enquanto uma carta aberta permite acomodar uma multiplicidade de visões e de situações sociais, tornando difícil - ou quase impossível - a obtenção de uma solução apropriada para os problemas da sociedade complexa.

Com força normativa, uma pragmática jurídica, a Carta Política teria como combustão uma virtuosa "força programática". Desse modo, a Constituição Programática seria pragmática. Ou seja, uma potência (não reconduzida à condição de possibilidade) que se realiza; uma utopia realizável, uma virtualidade provinda da virtus publica.

No início, o direito positivo inerente ao processo civilizatório estabelece diretrizes mínimas para a organização da sociedade e a busca pela paz. Todavia, este mesmo positivismo se torna, em razão da ruptura com os valores e com as pessoas, uma forma estática, inanimada e anacrônica de alcançar o processo civilizatório, perfazendo-se em mera fonte, ou reserva, de defesa contra o ativismo atávico. Como medium, atuaria a eficácia dos direitos fundamentais assegurados pelo Princípio da Constituição: integridade, integralidade. Como consequência, a ocorrência da sociabilidade e a fluência do espaço público não privatizado. Então, a Constituição desenhada em processo constituinte legítimo se revitalizaria na Política, enquanto Polis.

A vontade de Constituição obriga a força normativa, mas obedece à força vinculante do processo civilizatório. Nesta espécie de baliza que circunda a imbricação entre a Constituição e a atividade interpretativa, é que este artigo encontra sua problematização, objetivando, assim, expor as virtudes e reveses da (trans)mutação constitucional, especialmente no que alcança efeitos concretos - e irreversíveis - na sociedade.

Tendo-se a Constituição como um texto perene, uma Carta Política que anuncia e denuncia os interesses do povo, seria a política capaz de alterar tanto o direito? E, seria o direito capaz de alterar tanto a política? Neste giro de sujeições é que se pretende apresentar as

\footnotetext{
${ }^{3}$ Para aqui especificar as diferenças entre os legisladores (representação popular) e os julgadores (técnicos do direito), distinguiremos entre o Magnetismo Social (que atinge a ambos os grupos) e Mimetismo Jurídico: com cópias e recopias do estrangeirismo jurídico em total descompasso com a realidade do homem médio em sua vida comum, mas em associação mimética ao realismo político de ocasião.
} 
proposições do presente artigo, para trazer a mutação constitucional, a transmutação constitucional, uma a interpretação constitucional a partir das ideias de Peter Häberle e o magnetismo social que influencia o papel contramajoritário do Supremo Tribunal Federal. Foi utilizado o método dedutivo, a partir da análise de conjuntura que se estabeleceu no país, no pós-2016, e a pesquisa do tipo bibliográfica para elaboração do texto.

\section{A MUTAÇÃO CONSTITUCIONAL E A MUTAÇÃO DA MUTAÇÃO CONTEMPORÂNEA: TRANSMUTAÇÃO CONSTITUCIONAL}

Uma das características mais acentuadas da Constituição é a sua incidência e permanência, não só em aspecto jurídico-normativo, mas também em aspecto político-social. Decorre disso a sua força normativa enquanto um documento rígido e, necessariamente, dinâmico, para que possa concretizar suas ideias, ou seja, é uma carta de ação que se efetiva na realidade.

O desafio da Constituição que se afirma como uma Carta Política é estar presente e fazer sentido, demandando não somente uma aplicação pura de seu texto, mas necessitando de ser interpretada para que tome parte na vida das pessoas. É neste sentido que verdadeiramente traz disposições e conceitos abertos, não porque é um diploma superficial, mas porque precisa ser "moldável" a todos, muitas vezes exigindo uma atuação que não precisa necessariamente de uma alteração textual, mas de verdadeira compreensão do que a Constituição quer dizer.

Como texto vivo, a Constituição diz sobre muitos assuntos, mas somente se faz ouvir pela ação de seus intérpretes, restando neste escorço a mutação constitucional, porque sua atuação deve ser no presente e para o futuro, esclarecendo, com notoriedade, que é contemporânea e dirigente, sob pena de se tornar retrógrada.

Por contemporaneidade entende-se que:

As Constituições têm vocação de permanência. Idealmente, nelas têm abrigo as matérias que, por sua relevância e transcendência, devem ser preservadas da política ordinária. A constitucionalização retira determinadas decisões fundamentais do 
âmbito de disposição das maiorias eventuais. Nada obstante isso, as Constituições não são eternas nem podem ter a pretensão de ser imutáveis. Uma geração não pode submeter a outra aos seus desígnios. Os mortos não podem governar os vivos. Porque assim é, todas as Cartas Políticas preveem mecanismos institucionais para sua própria alteração e adaptação a novas realidades. Isso não quer dizer que essa seja a única hipótese de mudança do conteúdo das normas constitucionais.

Com efeito, a modificação da Constituição pode dar-se por via formal e por via informal. A via formal se manifesta por meio da reforma constitucional, procedimento previsto na própria Carta disciplinando o modo pelo qual se deve dar sua alteração. Tal procedimento, como regra geral, será mais complexo que o da edição da legislação ordinária. De tal circunstância resulta a rigidez constitucional. Já a alteração por via informal se dá pela denominada mutação constitucional, mecanismo que permite a transformação do sentido e do alcance de normas da Constituição, sem que se opere, no entanto, qualquer modificação do seu texto. A mutação está associada à plasticidade de que são dotadas inúmeras normas constitucionais. (BARROSO, 2010, p. 123-124)

Ao passo que, por dirigibilidade, compreende-se:

Uma constituição dirigente, como se viu a propósito do princípio da igualdade de oportunidades, pressupõe que o Estado por ela conformado não seja um "Estado mínimo', garantidor de uma ordem assente nos direitos individuais e no título de propriedade, mas um Estado social, criador de bens colectivos e fornecedor de prestações. Para uns, isso significa a compreensão democrática e social do Estado de Direito; para outros, isso é o caminho do novo Leviathan, da ditadura de todos sobre todos, pois uma crescente produção de bens públicos através de uma crescente produção de leis e de financiamento colectivo aniquila a espontaneidade da ordem social e do modelo constitucional contratual. (CANOTILHO, 1994, p. 391)

Por mutação constitucional, consagra-se a ideia de uma alteração da Constituição no que diz respeito aos limites e alcances do sentido de seu texto, sem que haja uma alteração material:

[...] um processo informal de alteração de sentidos, significados e alcance dos enunciados normativos contidos no texto constitucional através de uma interpretação constitucional que se destina a adaptar, atualizar e manter a Constituição em contínua interação com a sua realidade social. Com a mutação constitucional não se muda o texto, mas lhe altera o sentido à luz e por necessidade do contexto. (CUNHA JÚNIOR, 2012, p. 263-264)

A mutação constitucional estabelece-se como uma adaptação do texto à sociedade, sem as formalidades e sem uma necessidade de reescrever os postulados originais, acrescentando ou suprimindo ideias que não se amoldam à convivência humana, correlacionando-se à questão do tempo e do espaço que separa o momento da concepção do texto com o momento da sua leitura e subsunção à realidade que se permite regular pela Constituição. Por isso, a mutação constitucional é uma interpretação que altera o significado da norma sem a necessidade de um processo legislativo. 
Com efeito, a tese da mutação constitucional é compreendida mais uma vez como solução para um suposto hiato entre texto constitucional e a realidade social, a exigir uma "jurisprudência corretiva", tal como aquela a que falava Büllow, em fins do século XIX (veja-se, pois, o contexto histórico): uma jurisprudência corretiva desenvolvida por juízes éticos, criadores do Direito" (Gesetz und Richteramt, Leipzig, 1885) e atualizadores da constituição e dos supostos envelhecimentos e imperfeições constitucionais; ou seja, mutações constitucionais são reformas informais e mudanças constitucionais empreendidas por uma suposta interpretação evolutiva. (STRECK; LIMA; OLIVEIRA; 2013, p. 60)

É considerável a validade da mutação na busca pela realização dos aspectos programáticos, ocasião em que se firma como uma forma de atuação contramajoritária que pode se refletir nas três funções do Estado: i) atuando o Judiciário - predominantemente pelo STF na leitura interpretacional dos conceitos abertos; ii) o Legislativo consolidando através de leis as diretrizes mais refinadas desses conceitos, trazendo um sentido mais próximo e específico às normas constitucionais; e, iii) o Executivo regulamentando os mecanismos para a efetivação das normas. É, portanto, um agir conjunto que deduz a síntese da independência e harmonia dos Poderes (art. $2^{\circ}$ da Constituição Federal). A mutação constitucional tem a capacidade de compartilhar entre os três poderes a criação do direito, deixando clara a permissão da política nesta tarefa que se consolida como uma alteração informal da Carta Política ${ }^{4}$.

Portanto, há uma função que anota uma relação específica com a tarefa programática e progressista, democrática e republicana (mais do que liberal) e pela qual fica clara a evolução da interpretação constitucional pela sua mutação, diminuindo a distância entre os direitos e as pessoas e possibilitando respostas imediatas e efetivas aos maiores dilemas sociais/morais.

Contudo, é estabelecida uma crítica quanto à potencial separação dos poderes, em uma situação que podem o Judiciário e o Executivo atuarem na criação do Direito, trazendo uma certa desvantagem ou usurpação da função do Legislativo. De um lado, o Poder Executivo pode se tornar ainda mais hipertrofiado e o Poder Judiciário pode monopolizar o direito, desde sua criação até a aplicação ao caso concreto ${ }^{5}$.

\footnotetext{
${ }^{4}$ Já se tem por clareza, neste caso, que a pretensa mutação constitucional não pode violar, violentar, o sentido, os preceitos e princípios de que é dotada a Carta Política; notadamente, no que se refere a ter o espaço público como concretização da Polis ("animal político" que interpreta a CF/88 democraticamente) e defesa intransigente dos direitos fundamentais sociais e individuais.

${ }^{5}$ Por aqui se encaminha toda a crítica recente, no país, ao chamado ativismo judicial; mormente, porque as interpretações criativas do ativismo costumam coadunar com a restrição de direitos.
} 
Outra crítica à mutação constitucional, especialmente vinculada ao Poder Judiciário, é que não haveria legitimidade nessa atuação criativa - ativismo judicial - mudancista do sentido da Constituição (em sentido regressivo), e por se tratar de um Poder que não goza de representatividade, ferindo assim a democracia e os interesses populares e podendo desencadear um totalitarismo judiciário.

É obvio que não há uma relação eletiva entre os membros do Poder Judiciário e o povo (ou não). No entanto, se a crítica da mutação constitucional se fundamenta na falta de legitimidade e na violação da democracia, em muito é vazio o seu conteúdo, pois embora representantes do povo - por um processo legal de eleições -, o Legislativo e o Executivo se tornam cada vez mais fiéis aos interesses pessoais das classes dominantes, dos lobistas e das empreiteiras que contribuem para os caixas de campanha e a manutenção hereditária dos "grandes nomes" da política brasileira.

\begin{abstract}
Ora, no cotidiano jogo de forças políticas, com o processo de formação de grupos políticos, de alianças, articulações e de apoios políticos das mais variadas ordens, cujos protagonistas são os órgãos do legislativo e executivo, as questões que frequentemente surgem podem dizer respeito a tudo, menos a decisões majoritárias e representativas da população. Isso significa que, no mundo político real, não há mais sentido "em submeter, de forma simplista, os vários ramos do government a análises baseadas em etiquetas como 'voz da maioria', 'democrático' ou 'não democrático"'. De mais a mais, no constitucionalismo contemporâneo, a noção de democracia não pode ficar retida e reduzida a uma simples ideia ou regra de maioria. As minorias também devem ter voz num sistema democrático, até porque maioria e minoria são, igualmente, manifestações da soberania popular. (CUNHA JÚNIOR, 2012, p. 215)
\end{abstract}

Esse descompasso entre o que é interesse popular - mais qualificadamente dizendo o interesse público - que torna os representantes institucionais do povo muito afeiçoados aos interesses das classes dominantes, se mostram evidentes em especial quando observamos as reformas na legislação trabalhista e também no próprio sistema previdenciário, que são feitas passando ao largo dos direitos sociais para atender aos interesses econômicos tanto do Poder Público - diminuindo os gastos com direitos fundamentais interesse primário e economia um interesse público secundário - como criando condições atrativas para a reprodução do modo capitalista. Não se pode olvidar do alerta de Bauman, para quem a elite global se apropria das riquezas de uma localidade, mediante um processo de exploração à distância. O que implica em uma falsa sensação de que se está diante de um benefício, vez que são construídas, por exemplo, estradas e instalações, são pagos os tributos ao Estado, no entanto, é deixada uma massa humana 
desprotegida, lesada e sem qualquer perspectiva de futuro, em termos de direitos trabalhistas e previdenciários, sem qualquer responsabilidade do empregador. (BAUMAN, 1999, p.13-15)

Esse modo de atuação possui semelhança com aquele adotado em regimes extremos, levando a um discurso nacionalista e de extrema valorização das classes hegemônicas de poder econômico e de condução da massa: grandes empresários, latifundiários, líderes religiosos, entre outros.

Em Habermas vemos o privatismo de que é tomado o Estado de Sítio, já plantado na formação burguesa da esfera pública:

\begin{abstract}
À autonomia dos proprietários no mercado corresponde uma representação pessoal na família aparentemente dissociada da coação social, é o carimbo autenticador de uma autonomia privada exercida na concorrência. Autonomia privada que, negando a sua origem econômica, exerce-se unicamente fora do domínio em que aqueles que participam do mercado se acreditam independentes, conferindo à família burguesa essa consciência que ela tem de si mesma. Tal consciência parece ser espontânea, parece ter sido fundada por indivíduos livres e manter-se sem coação; ela parece repousar na permanente comunhão amorosa dos cônjuges; ela parece resguardar aquele livre desenvolvimento de todas as faculdades que distinguem uma personalidade culta. Os três momentos - do livre arbítrio, da comunhão de afeto e da formação - conjugam-se num conceito de humanidade que se pretende que seja inerente a todos os homens, definindo-os certamente enquanto seres humanos: a emancipação que ainda ressoa quando se fala do puramente ou simplesmente "humano", uma interioridade a se desenvolver segundo leis próprias e livre de finalidades externas de qualquer espécie (...) A família desempenha exatamente o papel que lhe é prescrito no processo de valorização do capital. (HABERMAS, 2003, p. 63, grifos nossos)
\end{abstract}

Traçando mais um paralelo, Hitler, por exemplo, queria um golpe prussiano (pelo Estado e "limpando" o próprio Estado) e não uma aliança com o lumpem, como se promovera na França com Luís Bonaparte: "Nós não somos revoltosos contando com o Lumpenproletariat" (FEST, 1976, p. 473). Mas, suas polícias (SA e SS) promoviam atos de puro banditismo: "ao lado disso, houve uma onda de arrombamentos, de pilhagens e raptos; as seções das SA praticavam isoladamente uma espécie de mercado humano selvagem, ao exigir altas quantias como resgate de adversários políticos detidos” (FEST, 1976, p. 473). A violência era o cerne das SA e, por isso, a "revolução legal” deveria mascarar tais ações ou justificá-las:

A tática da "revolução legal" não se consumaria e não teria obtido tanto efeito sem a "segunda palavra mágica" graças à qual Hitler promoveu o "despertar nacional". Essa noção não só fornecia uma justificação revolucionária para os numerosos atos de violência, em parte descontrolados, em parte dirigidos, mas também oferecia ao país, ainda afetado em sua consciência nacional, uma senha sugestiva através da qual se podia disfarçar com habilidade os imensos desejos de poder do regime. A começar 
pela atitude dos conservadores que ainda dominavam Hitler no gabinete, até os amplos círculos da opinião pública burguesa, aquela combinação de violência intimidatória e fraseologia nacionalista, que conferia a todas as vinganças um clima patético quase alucinante, foi traumatizante (FEST, 1976, p. 474).

Há três elementos básicos que muito bem se combinam e se contaminam: (i) Inconsciência sistêmica: não lhes permite ver que este seu suposto valor de uso, não passa de consumismo fetichista - no que são iguais a todos, no nivelamento por baixo. Apenas são mais nocivos porque, com mais ilustração e "retórica crítica" (sic) se colocam em posição de superioridade, repetindo bordões (anti-consumistas) e discursos de autoridade; (ii) Culto à personalidade: além, é claro, de se locupletarem, vez ou outra, com o "culto à personalidade" (a publicação reiterada de fotos na web, é um bom indício de narciso...); (iii) Cinismo: o método aprovado não \&ea cute; o da ironia, sarcasmo contra a hipocrisia, de um Benjamin (1987) ou Balzac (2002), mas sim o cinismo que protege o "crítico" contra as alegações do "valor de uso". Como em seu cinismo refuta ser ele mesmo um consumidor ávido por novidades e bugigangas de "alta tecnologia", continua a só ver fins (e não "valores quanto a meios").

A propósito, o que torna a mutação constitucional espúria é a utilização que se afasta dos objetivos mais importantes da Constituição, que a descamba para uma inusitada ditadura do Supremo ou simplesmente, monopólio da última palavra sobre a Constituição. Se, de um lado, constitucionalizando-se diversos temas, ocorre a judicialização da política que denuncia descontentamento e ineficiência dos governantes e dos legisladores, de outro, há expansão das competências do Supremo Tribunal Federal, por: a) técnicas de interpretação, b) criação de normas infraconstitucionais pelas declarações de inconstitucionalidade por omissão, c) invalidação de norma legal ou administrativa com base em princípio constitucional abstrato, d) a criação ou alteração de norma constitucional através de sentença aditiva ou modificativa do texto constitucional e e) a imposição de medidas concretas aos demais Poderes, demonstram um aprimoramento das técnicas jurisdicionais, mas ao mesmo tempo a prevalência de um comportamento juriscêntrico e que não considera as opiniões de fora da Corte (GODOY, 2017, p. 59-60).

É nessa perspectiva que a mutação constitucional precisa acomodar aspectos do direito e da política, permitindo a influência de um no outro, encontrando os limites e potencialidades da interpretação constitucional, fortalecendo seus objetivos na força vinculante do processo civilizatório. Ou seja, a legitimidade da mutação constitucional se dá não no aspecto da 
representatividade, mas na atividade de dizer as expressões da Constituição conforme as exigências do todo que compõe o povo e do Estado Democrático e Social de Direito.

$\mathrm{Na}$ medida em que a mutação constitucional se desvia do processo civilizatório, dos valores plurais e da própria realização dos direitos fundamentais, se assemelha à Transmutação Constitucional (MARTINEZ; et al, 2018) que é um retrocesso político-jurídico ao se desvincular do conteúdo da Constituição. A Transmutação Constitucional:

Sumariamente, implica no retraimento da democratização constitucional em virtude do aprofundamento do fascismo político.

(...)

Desde o Preâmbulo da CF/88 é notável o conteúdo libertário, de emancipação e de aprofundamento da democracia no livre trânsito das divergências ideológicas compatíveis com a Política: o espaço público em que reina o animal político. Com o retrocesso político-jurídico, vale dizer de toda a condição humana, perde-se do prisma constitucional a referência de que a democracia obedece à crença na perfectibilidade. Com o que igualmente reflui o amplo e complexo processo civilizatório: diante do fascínio pelo fascismo, nas ruas, nas mídias e nos poderes, o aprofundamento democrático não é mais viável, nem requerido.

Assim, entendemos que não há Política - que não se confunde com Maquiavel (1979) - sem que haja a prospecção da luta política resultando na Luta pelo Direito (Ihering, 2002) e que, portanto, a Transmutação Constitucional serve a outros fins que não os da emancipação, democratização e alargamento da cidadania. Não há democracia ativa (Benevides, 1991) sem proposição e aferimento de demandas políticas e sem a propositura legítima pela participação em proveito de direitos, liberdade e garantias. (MARTINEZ; et al., 2018)

A natureza jurídica da Transmutação Constitucional, assim como a mutação, é a do criacionismo constitucional, porém no sentido reverso, ou seja, é uma involução políticojurídica. Nesta situação, a Transmutação Constitucional tem por principal modo de autuação o uso excessivo dos meios de exceção e de coerção, trazendo uma situação de eliminação das múltiplas concepções, implicitamente realizando a erosão dos direitos fundamentais e do acesso à Política.

A natureza jurídica da Transmutação Constitucional a que estamos submetidos, portanto, não é sinalizada pela dominação racional-legal (Weber, 1979), não é pressuposto de que o Estado de Direito é preferível - mesmo com falhas estruturais à violência desorganizada. Mas, sim, a institucionalização de domínio marcado pelo martírio individual e social; domínio, não dominação. (MARTINEZ; et al, 2018)

O entrelaçamento da mutação e da transmutação apontam para o caminho da regressão constitucional, encontrando na Transmutação Constitucional a hermenêutica regressiva mais severa, que atinge direitos e valores até então intangíveis sob o aspecto de uma retirada do ordenamento jurídico. Neste núcleo, a interpretação constitucional deixa de pensar os direitos 
fundamentais como objeto de ampliação e volta-se à aniquilação da pluralidade e da democracia.

\section{POR UMA "NOVA" INTERPRETAÇÃO CONSTITUCIONAL}

A partir dessa ideia de mutação constitucional, que consegue acomodar aspectos positivos e negativos, o vetor de legitimidade fica estabelecido na vinculação das interpretações ao processo civilizatório ${ }^{6}$. Por certo que há muito o que se respeitar, especialmente aos aspectos históricos, culturais e sociais que se exprimem na Carta Política, com maior incidência sobre os direitos fundamentais sociais e individuais.

Pois, é um axioma que os direitos fundamentais não podem ser objeto de monopólio, seja pela maioria do povo (em desconsideração às minorias), seja pela atuação do Estado, com destaque ao Supremo Tribunal Federal. É neste sentido que a interpretação constitucional passa a trilhar caminhos cada vez mais horizontais e abertos, não se restringindo à comunis opinio que não permite a voz das minorias e muito menos às frias salas onde se produzem as sentenças ${ }^{7}$. É preciso considerar a pluralidade de interpretações que acontece fora dos tribunais e gabinetes:

O espaço público poderá ser, futuramente, um dos mais importantes polos políticos de conscientização participativa da cidadania; e sem dúvida a primeira das estradas por onde, nos distritos de sua autonomia social, há de caminhar, em preparação constitutiva, a democracia direta do terceiro milênio. Democracia que assume o status de direito da quarta geração, direito cuja universalidade e essencialidade compõem o novo ethos que o gênero humano, em sua irreprimível vocação para a liberdade, a igualdade e a justiça, toma por inspiração.

Em face, pois, do malogro das formas representativas clássicas, o espirito democrático de nossa época se inclina para a rejeição do formalismo tradicional, em ordem a desterrar a supremacia liberal do poder, enquanto elemento institucionalizador de privilégios e desequilíbrios de classe. (Bonavides, p. 279)

\footnotetext{
6 O mudancismo interposto no país, no pós-2016, atende a interesses de mercado, de neoliberalismo e neocolonialismo, sem olvidar das interpretações restritivas de direitos constitucionais, que, em suma, designariam tempos de um cesarismo regressivo e repressivo (Gramsci, 2000) - na esteira de uma Transmutação Constitucional de retorno à configuração da Constituição Polaca.

${ }^{7}$ É a isto que referenciamos o Mimetismo Jurídico, quando se encontram o tecnicismo jurídico com o senso comum, em desconformidade à teleologia societal requerida pela Ciência do Direito, e tão praticada ultimamente pelas cortes nacionais em atendimento aos reclamos do realismo político. Esquecem-se as cortes, por exemplo, de acentuar basicamente o Princípio da Negação do Retrocesso Social.
} 
A interpretação constitucional não pode encontrar na mutação constitucional uma incontestável solução para os problemas de ordem pública e que têm um intenso impacto sobre a vida e o direito das pessoas, pois:

\begin{abstract}
Nessa linha, a decisão do Supremo Tribunal Federal, por mais que esteja imbuída de um sentido pragmático e sustentada na melhor ciência jurídica, pode (e, certamente assim será) representar uma afirmação do imaginário jurídico que justamente levou àquilo que hoje é combatido: o excesso de recursos e a multiplicação das demandas. Se o Supremo Tribunal Federal pode fazer mutação constitucional, em breve essa "mutação" começará a gerar - como se já não existissem à saciedade23 - os mais diversos frutos de cariz discricionário (portanto, positivista, no sentido em que Dworkin critica as teses de Hart). Exatamente porque no Brasil cada um interpreta como quer, decide como quer e recorre como quer (e isso parece recorrente na cotidianidade dos fóruns e tribunais da República), é que faz com que cresçam dia-adia as teses instrumentalistas do processo, como que a mostrar, a todo instante, que as teses de Oscar Von Büllow não foram (ainda) superadas. A solução tem sido essa: corte-se o acesso à justiça. Sob pretexto de agilizarmos a prestação jurisdicional, criamos mecanismos para impedir o processamento de recursos. E quem perde com isso é a cidadania que vê assim negada a jurisdição. (STRECK; LIMA; OLIVEIRA; 2013, p. 60)
\end{abstract}

Häberle (1997), ao refletir sobre a hermenêutica constitucional, traz a noção da necessidade de adequar tal atividade ao que denomina de "sociedade aberta", qual seja, uma sociedade pluralista e multidinâmica que ao mesmo tempo concentra interesses, consensos e dissensos.

A partir de uma concepção de que a interpretação judicial ou jurisdicional da Constituição não é a única, Häberle (1997) adota a ideia de que cidadãos, grupos de interesse, órgãos estatais, o sistema público e a opinião pública são notáveis forças produtivas de interpretação que não podem ser desconsideradas na atividade de buscar o sentido e o alcance das expressões da Constituição. Esta Vontade de Constituição (Hesse, 1991), entretanto, tem de se amoldar ao sentido global expresso na $\mathrm{CF} / 88$, especialmente de acordo ao Princípio Democrático (Canotilho, s/d) e não seguir a "voz rouca das ruas", sedenta de justiciamento que tem respaldo em práticas sociais e pautas políticas proto-fascistas: o Executivo, por meio do Decreto 9.759, de 11 de abril de 2019, fez calar uma série de colegiados públicos e populares tais como o Conselho Nacional dos Direitos da Pessoa com Deficiência (CONADE), Conselho Nacional de Combate à Discriminação e Promoção dos Direitos de LGBT (CNCD/LGBT), Comissão Nacional de Educação Escolar Indígena., Comitê Nacional de Educação em Direitos Humanos (CNEDH), Comitê Intersetorial de Acompanhamento e Monitoramento da Política Nacional para a População em Situação de Rua, entre outros. 
$\mathrm{O}$ ato vilipendiador do texto constitucional foi questionado, mas não houve uma manifestação da jurisdição no sentido da guarda da Constituição que consagra em diversos dispositivos (art. 187, VI; art. 194, VII; art. 198, I, II e III; art. 204, I; art. 205; art. 206; art. 225; e art. 227) deveres sociais e responsabilidades públicas. Os direitos fundamentais e sociais não podem ser contabilizados sem a observância e a fruição das ações políticas e institucionais no formato de Colegiados, uma vez que requerem a ação tripartite ou quadripartite, para que consigam alguma eficácia de política pública.

Em que pese esse mandamento constitucional, preferiu o STF no julgamento da ADI $6121 \mathrm{MC}$ apenas suspender a eficácia do $\S 2^{\circ}$, do art. $1^{\circ}$ do Decreto 9.759, de 11 de abril de 2019, por entender que o ato presidencial acabaria por extinguir colegiados instituídos por lei e por ser dotado de vagueza e abstração. Ainda que dos amplos votos possam ser retiradas notáveis sustentações de valores fundamentais, tais como a participação popular, a democracia, a razoabilidade e a própria essência dos Poderes independentes e harmônicos, permeia o ranço proto-facista em diversas passagens que acabam por dar vazão ao pensamento de que os conselhos são desnecessários, onerosos, inoperante, ineficazes. É bem provável que se o ato do Executivo tivesse sido melhor detalhado - isso porque foi feito a atropelos -, muitos colegiados de vital importância não estariam mais entre nós. Embora o STF tenha atuado, o fim não justifica o meio, isto quer dizer, o debate não foi a nível de guarda da Constituição, mas apenas se reduziu a suprimir um decreto mal redigido.

Assim, a partir de uma leitura do texto escrito da Constituição, deveria ser possível saber o que ela é e o que sua força normativa representa; porém, é pela interpretação constitucional que são dados os sentidos e estabelecidos os alcances de suas expressões. Este aspecto deontológico da Constituição, estabelecendo-se o dever-ser do Estado de Direito, para que não se torne mera carta de intenções, precisa ser interpretado à luz de sua força normativa, que não reside, tão-somente, na adaptação inteligente a uma dada realidade mas busca converte-se em força ativa, que se assenta na natureza do presente (HESSE, 1991, p. 14-19).

É necessário reconhecer, pois, que:

O Direito não existe abstratamente, fora da realidade sobre a qual incide. Pelo contrário, em uma relação intensa e recíproca, em fricção que produz calor mas nem sempre luz, o Direito influencia a realidade e sofre a influência desta. A norma tem a pretensão de conformar os fatos ao seu mandamento, mas não é imune às resistências que eles podem oferecer, nem aos fatores reais do poder. No caso das mutações 
constitucionais, é o conteúdo da norma que sofre a influência desta. (BARROSO, 2010, p. 127)

É no sentido de entender que o Direito não existe fora da realidade e não pode ser aplicado de forma oposta à realidade, que se deve construir a interpretação democrática e ética - distante dos reclamos sociais vingativos e do senso comum que habita o tecnicismo jurídico. Pois bem, a Constituição precisa se tornar um diploma atemporal, sem que seja anacrônica, e, exatamente, por ser uma Carta Política. Por isso:

[...] partir da aplicação da própria Constituição, a partir da concretização dos direitos nela previstos, que se pode atualizar e revigorar sua potência, sua carga revolucionária, no Estado Constitucional Democrático. A potência revolucionária da Constituição aparece quando ela é aplicada, quando ela é também decisão política fundamental e, assim, fundamenta decisões políticas e jurídicas, digamos, de uma segunda ordem, que garantem direitos e seu exercício, inclusive o direito de dizer que uma norma constitucional é inconstitucional e, por isso mesmo, deve ser desobedecida. CHUEIRI, 2013, p. 34).

Para alcançar uma interpretação constitucional mais próxima da concretização da Carta Política, em termos de sua concretização, é imprescindível ouvir os clamores populares. Entretanto, embora necessário seja observar a opinião popular, não se pode deixar de considerar que:

\footnotetext{
A sintonia com a opinião pública envolve diversas nuances. Por vezes, grupos de pressão bem situados são capazes de induzir ou falsear a real vontade popular. Em razão disso, a opinião pública manipulada ou não, sofre variações, por vezes abruptas, em curto espaço de tempo. Será preciso, assim, distinguir, com as dificuldades previsíveis, entre clamor público, paixões do momento e opinião sedimentada. (BARROSO, 2012, p. 407-408)
}

A vontade popular precisa ser encarada conforme a ideologia exposta na Constituição (no caso do Brasil, o Estado democrático de Direito) e, diante disso, as opiniões que atentam contra isso não são a expressão de uma interpretação constitucional, mas sim uma tentativa de impor contradireitos e vontades de estratos sociais que buscam dominar a sociedade, muitas vezes se valendo do poder do Estado para vencer uma espécie de "guerra civil" encenada e negar direitos.

O público está esvaziado de sentido porque não tem força; porque nunca teve coerção suficiente, isto é, funciona como mero reflexo ampliado do privado. Como vimos, este aburguesamento do espaço público, na verdade, trazendo à risca o nascimento do "novo espaço público", coincidiu com um processo de privatização: há um público-privado. Em síntese, o 
público é privado porque o cidadão (sujeito de direitos humanos: reais e virtuais) já nasceu privado. Portanto, este público-burguês não pode escapar a seus limites:

\begin{abstract}
A esfera pública burguesa desenvolvida baseia-se na identidade fictícia das pessoas privadas reunidas num público em seus duplos papéis de proprietários e de meros seres humanos (...) A fórmula básica de Locke quanto à preservation of property subsume, numa só linha e de um só fôlego, sem qualquer constrangimento, sob o título "propriedade", life, liberty and estate: tão fácil conseguia ser, naquela época segundo uma distinção do jovem Marx, identificável a emancipação política com a emancipação "humana". (HABERMAS, 2003, p. 74)
\end{abstract}

Como no Brasil o Supremo Tribunal Federal detém a palavra final sobre o sentido e o alcance da Constituição, é necessário que sua percepção acerca da opinião pública e do juriscentrismo esteja em muito afinada para definir com precisão os termos da Carta Política, e sem deteriorar direitos em nome de uma maioria - muitas vezes enlouquecida -, e sem tornar endógeno o processo civilizatório, modulando direitos e programas de acordo com as concepções pessoais a respeito da interpretação constitucional.

Neste escorço, é necessário um alinhamento do pensamento da Corte Superior ao aspecto plural, ou seja, a interpretação da Constituição não pode eliminar as diferenças no sentido de estabelecer uma homogenia, mas deve buscar um consenso das heterogenias, buscando o respeito às múltiplas existências e garantindo, com igualdade, sua participação nos processos interpretacionais.

É com notoriedade que o pensamento de Häberle (2008b) se destaca, pois é possível identificar sua ideia pluralista, que não se limita no pensar a Constituição no recorte do direito, mas reconhecendo sua vinculação à cultura, à filosofia e à realidade que se encontra inserida. É por isso que uma Constituição democrática é considerada uma Carta Política, sua formação e sua vinculação aos aspectos políticos plurais e abertos a tornam legítima para representar o povo, considerando as realidades sociais e culturais.

Ao incorporar ao contexto jurídico a música, a poesia, a literatura, a arquitetura, as artes cênicas e a pintura, Häberle (2008a) trouxe uma visão policrômica, multifacetada, democrática, transdisciplinar ao Direito e à Constituição, tornando os aspectos por vezes frios e anacrônicos, mais reais e palpáveis; trazendo a força normativa para perto da sua realização, queria o autor, alcançar o transcultural. 
O constitucionalista alemão ainda tinha como meta articular uma síntese multicultural - objetivo não facilitado porque nos deparamos com uma globalização incerta e indeterminada para a maioria dos povos pobres. Além disso, nossa dificuldade maior é que o direito à interpretação - como parte da luta política - não sobrevive aos desvios não-democráticos, isto é, para haver legitimidade, é preciso ter clareza de que Häberle (1997) escreveu visando o aprofundamento democrático e não o seu oposto: o cesarismo regressivo e repressivo (GRAMSCI, 2000) ou efetivamente proto-fascista. Como plano metodológico e epistemológico, Häberle (2008) nos convida a uma necessária interpretação constitucional sob parâmetros sociais, econômicos, jurídicos e deontológicos.

Seu intento maior é converter a cidadania em um imenso fórum aberto da Constituição, onde os destinatários são seus próprios artífices. Com efeito, é preciso esclarecer que a convicção do Pluralismo Constitucional não deve ceder aos individualismos, a fim de se constituir como real reflexo do interesse público. Cabe a diferenciação entre respeitar o individual como um complexo de características da pessoa, como unidade política exclusiva, e o individualismo como um pensamento que tende a destacar a si próprio em sobreposição ao Outro, sendo este rechaçado. Ao passo que o respeito ao indivíduo, fluindo a cidadania na Constituição Aberta ao Princípio Democrático, afeiçoa-se com a construção de uma sociedade justa, digna e plural, e o individualismo corrobora em uma sociedade injusta, seletiva e fechada.

À luz conceitual do pluralismo procura fortalecer uma visão de duplo alcance: subjetivo individual; objetivo institucional. O intento de Häberle (2008) é verificar na cultura os laços próprios à legitimação constitucional, como um processo político no interior de um amplo conceito de pluralismo (como axiologia e hermenêutica).

Trata-se, portanto, de um pluralismo constitucional não-dogmático, pois não busca se impor como prefeito, mas se opor à ideia de que há uma Carta Política acabada. Por outras palavras, o pluralismo alcança as noções de uma ordem normativo-constitucional em permanente construção e vinculada ao processo civilizatório. Politicamente, esta hermenêutica constitucional traz o Princípio da Dignidade Humana e é receptiva a pontos de vista angulares e até opostos ou contraditórios. Sua perspectiva prima pela inclusão não-excludente, combatente da lógica dos meios jurídicos de exceção, em que se inclui a exclusão. 
A Constituição axiológica e deontológica é pluralista, opondo-se ao modelo constitucional totalitário, integrista e fundamentalista; em que não fiquem à sombra valores como: diversidade; cidadania ativa; soberania autonômica. Desse modo, sua obra acaba por se converter num gigantesco poema-sinfônico do constitucionalismo democrático (uma "reserva teoricamente possível”). Como seguidor de Konrad Hesse (1991), Häberle (2008) vê o vigor ou a força normativa subjacente à Constituição, como se fora sua síntese cultural.

Nessa percepção transcultural e de multiplicidade de alternativas, transborda o eixo de sua base conceitual: "realidade; possibilidade; necessidade". Há um nítido esforço por resultar em uma mescla entre cultura e direito (Justiça Constitucional), informando as formas e os limites em que atua, realisticamente, a normatividade jurídica constitucional concernente ao Estado Social e à cidadania.

A constituição é uma comunidade aberta. Quando se trata do direito aplicado ao homem médio em sua vida comum, não há clausura em que os significados não possam desviar das hostes tradicionais de poder de interpretação:

[...] no processo de interpretação constitucional estão potencialmente vinculados todos os órgãos estatais, todas as potências públicas, todos os cidadãos e grupos, não sendo possível estabelecer-se um elenco cerrado ou fixado com numerus clausus de intérpretes da Constituição (Häberle, 1997, p. 13).

O jurista, o pedagogo, o político deveriam perguntar-se o que faz de um autor um clássico, para assim aprendermos a ver a Constituição com os olhos do cidadão - o homem médio em sua vida comum: “[...] qual é o modo de vigência de clássicos no Estado constitucional?" (Häberle, 2016, p. 56).

Ao que parece, a interpretação transcultural da Constituição e do Direito é o caminho mais seguro de garantia de um Estado Democrático e Social de Direito, suficientemente eficaz ao combate da mutação constitucional atávica que insiste em permear os pensamentos jurídicos e a produção das decisões que não se inibem nem com a vedação ao retrocesso. 


\section{MAGNETISMO SOCIAL E CONTRAMAJOTARIEDADE}

Após referenciar uma interpretação plural como uma "nova" alternativa, que se coloca em aspas justamente por não ser uma descoberta do agora, mas por ser verdadeiro processo de relembrar uma consciência que sofreu corrosão, ficaria, em certa medida, contraditório acomodar um pensamento do todo com a ideia de contra todos.

Primeiro, cabe trazer o Magnetismo Social, que seria basicamente a ideia de as pessoas terem atração pelo que gostam e repelirem o que não gostam. O que, aparentemente, remete à uma certa normalidade, que acaba criando blocos sociais; todavia, a anormalidade advém do bloqueio social.

Tanto no Direito como na Política, a incidência do magnetismo social é inevitável, os juízes e os políticos são pessoas e por isso têm a capacidade de influenciar e ser influenciados, de atrair, repelir, serem atraídos e serem repelidos. Por isso é importante que os juízes sejam politizados e não políticos, no sentido de se tornarem governantes. Não há como estabelecer uma neutralidade quando se trata de assuntos sociais, culturais e políticos, todavia, o que deve nortear o pensamento interpretacional é o Direito e a Constituição, que precisam da realidade para a construção de soluções que façam prevalecer o direito e as garantias fundamentais. $\mathrm{O}$ magnetismo social impõe o desvio da razão, situação em que o atraído pela aceitação, prestígio e simpatia da maioria, ao invés de se preocupar com as fissuras sociais, visa a aclamação e a hegemonia, arvorando-se na aclamação popular ao invés de buscar fundamentos em um Estado Democrático e Social de Direito que visa a garantia dos direitos fundamentais.

A ideia de contramajoritariedade vem justamente no sentido de o Supremo Tribunal Federal, por vinculação, se opor ao ideário social que fulmina o que detesta. Neste sentido, enquanto o Magnetismo Social atrai um maior número de pessoas a uma determinada ideia, outras ideias e ideais (democráticas) vão formando polos de minorias, que precisam ter a existência e o direito preservados. Daí se falar que a Corte "deveria emprestar" sua força para o lado oposto ao da opinião dominante para garantir a pluralidade. Afinal: 
objetos jurídicos. A legitimidade de atuação jurisdicional deve estar vinculada a sua racionalidade e a sua capacidade de justificação. (CAMBI, 2011, p. 200)

São evidentes as derrotas da Constituição diante da influência do magnetismo social nas decisões da Corte Constitucional, como, por exemplo, no HC 152752/PR que permitiu a execução da pena privativa de liberdade após o esgotamento do pronunciamento judicial em segundo grau, sem trânsito em julgado. Muito embora o tema seja debatido nas ADCs 43 e 44, a Constituição Federal prevê:

Art. $5^{\circ}(\ldots$.

LVII - ninguém será considerado culpado até o trânsito em julgado de sentença penal condenatória;

LVIII - o civilmente identificado não será submetido a identificação criminal, salvo nas hipóteses previstas em lei;

A interpretação do direito de recorrer em liberdade merece a observação de um contexto histórico, após a superação da ditadura militar, que aconteceu antes da promulgação da Constituição Federal de 1988, existia um consenso sobre o valor da liberdade em todas as suas facetas, como se espera de um ambiente politicamente redemocratizado. Com isso, antes mesmo da vigência da disposição constitucional já era esperado que não mais haveriam prisões arbitrárias e sem qualquer fundamentação fática e jurídica. Todavia, entendeu o legislador constituinte por trazer positivado o postulado de exaurir em liberdade do direito de defesa na seara penal como uma garantia de integridade de um direito fundamental individual.

Ocorre que desde 2016, pelo menos, é debatida no STF a extensão da expressão "trânsito em julgado", excepcionalmente com um viés de que a prisão em segundo grau é possível como uma medida de exequibilidade da sentença penal e que a presunção da inocência se confunde no exacerbo da (má e duvidosa) utilização dos sistemas recursais. Claramente, o precedente histórico se desviou da sua realidade experimentada e se vinculou ao presente, para trazer uma solução ao problema contemporâneo do sistema carcerário - que nem é tão contemporâneo assim - e também se rendeu à opinião e à pressão pública ${ }^{8}$, que reconheceu nos julgadores que denegaram o Habeas Corpus os heróis da nação brasileira ${ }^{9}$.

\footnotetext{
${ }^{8}$ Disponível em: https://g1.globo.com/politica/noticia/datafolha-aponta-que-53-querem-lula-preso-e-43-dizemque-ex-presidente-nao-vai-disputar-eleicao.ghtml. Acesso em: 04 mai. 2018.

${ }^{9}$ Disponível em: http://g1.globo.com/globo-news/jornal-das-dez/videos/v/camarotti-ministros-do-stf-avaliamque-minoria-quer-mudanca-sobre-prisao-em-2a-instancia/6649516/. Acesso em: 27 jun. 2018.
} 
Ser contramjoritário, significa assumir um ônus de receber críticas públicas para garantir a existência da pluralidade e das minorias, tal qual o Supremo Tribunal Federal já julgou em outros casos, como na ADPF 132 que tratou da controvérsia sobre o reconhecimento da união homoafetiva, numa nítida interpretação em prol dos direitos fundamentais.

\section{CONCLUSÃO}

O Brasil nunca experimentou um período de estabilidade da democracia tão grande quanto o trazido após a queda do regime militar, com os movimentos que originaram a Constituição Federal de 1988. No entanto, o realismo político perfilado em orientação fascista desde o pós-2016, em atendimento aos preceitos de "mercado", impõe pesados fardos às camadas, setores, grupos e classes sociais mais desassistidos ou historicamente violados em direito e em dignidade.

Assim, quando as cortes de direito - via de regra - ouvem o clamor social, a voz rouca das ruas, sem a necessária mediação dos princípios teológicos do direito que informam o processo civilizatório, incentivam e dão vazão a práticas societais nocivas à democracia, à República, ao Estado de Direito. Salvo exceções, as cortes já instadas por privilégios nobiliárquicos, dão seguimento a posições do Legislativo e do Executivo que variam entre, ferir fatalmente o Estado Laico e permitir que grávidas trabalhem em condições insalubres aos bebês e a si mesmas.

Efetivamente, desde que o pós-2016 implementou como "regra" mergulhar a interpretação constitucional nas várias seletividades requeridas pelos Grupos Homogêneos de Poder, a própria Constituição foi reinterpretada ao revés de seus valores, princípios e conotações humanistas e sociais, fazendo surgir quase que uma nova Constituição, nem promulgada, nem outorgada, mas metamorfoseada a contento de uma maioria que apoia um direito alucinante. E isto, evidentemente, é o exato contrário do que se projetou como ideal democrático e ético - processo civilizatório - da Vontade de Constituição e de Sociedade Aberta. 
Desvirtuando-se das funções originalmente atribuídas ao Guardião da Constituição, toda vez que rende-se a usar a mutação constitucional como transmutação, opera-se em hermenêutica regressiva e predatória o resultado alterador do Direito. A proposta de uma nova interpretação que realinhe-se com as forças normativas da Constituição e com os aspectos plurais, multifacetados e transculturais como querido por Häberle, se apresenta como um caminho para a reabilitação da práxis contramajoritária que defende e garante os direitos fundamentais, fornecendo condições para a ampliação do seu catálogo e permitindo que as minorias possam mante-se vivas em uma sociedade que se pauta pela eliminação do outro, do diferente.

No País, repetindo-se os piores lances da história republicana, só há vontade de poder que sirva ao capital, bem como se solidificam restrições ao pluralismo societal, em que a própria forma-Estado assume para si a tarefa das raízes do fascismo cotidiano e institucional, julgadores e legisladores acabam se tornando extensões de um executivo que se nutre das forças sociais, colocando em extinção o próprio povo que outrora era fonte detentora do poder. Toda a legitimação política se transforma num processo de confisco das causas sociais e da busca pela Constituição aberta e em constante construção vinculada ao processo civilizatório.

\section{REFERÊNCIAS BIBLIOGRÁFICAS}

BARROSO, Luís Roberto. Curso de direito constitucional contemporâneo: os conceitos fundamentais e a construção do novo modelo. São Paulo: Saraiva, 2010.

O controle de constitucionalidade no direito brasileiro: exposição sistemática da doutrina e análise crítica da jurisprudência. São Paulo: Saraiva, 2012.

BALZAC, Honoré. Ilusões Perdidas. São Paulo: Companhia das Letras, 2002.

BENJAMIN, Walter. Obras escolhidas - Magia e Técnica, Arte e Política. $3^{\text {a }}$ ed. São Paulo: Brasiliense, 1987.

BONAVIDES, Paulo. Teoria constitucional da democracia participativa: por um direito constitucional de luta e resistência, por uma nova hermenêutica, por uma repolitização da legitimidade. Malheiros, São Paulo: 2001. 
CAMBI, Eduardo. Neoconstitucionalismo e neoprocessualismo: direitos fundamentais, políticas públicas e protagonismo judiciário. $2^{\mathrm{a}}$ Edição. São Paulo: Editora Revista dos Tribunais, 2011.

CANOTILHO, José Joaquim Gomes. Constituição dirigente e vinculação do legislador. Coimbra: Coimbra ed., 1994. s/d.

Direito Constitucional e Teoria da Constituição. $4^{\mathrm{a}}$ Edição. Lisboa-Portugal: Almedina,

CHUEIRI, Vera Karam de. CONSTITUIÇÃO RADICAL: UMA IDEIA E UMA PRÁTICA. Revista da Faculdade de Direito UFPR, Curitiba, PR, Brasil, v. 58, dez. 2013. ISSN 2236-7284. Disponível em: <http://revistas.ufpr.br/direito/article/view/34863/21631>. Acesso em: 17 abr. 2018.

CUNHA JÚNIOR, Dirley da. Curso de direito constitucional. Salvador: JusPodivm, 2012.

FEST, Joachim. Hitler. 4ª ed. Rio de Janeiro: Nova Fronteira, 1976.

GODOY, Miguel Gualano. Devolver a constituição ao povo: crítica à supremacia judicial e diálogos institucionais. Belo Horizonte: Fórum, 2017.

HABERLE, Peter. Hermenêutica Constitucional - A sociedade aberta dos intérpretes da constituição: contribuição para a interpretação pluralista e "procedimental" da constituição. Tradução: Gilmar Ferreira Mendes. Porto Alegre: Sergio Antonio Fabris Editor, 1997.

Os problemas da verdade no Estado Constitucional. Porto Alegre: Sergio Antonio Fabris, 2008a.

Pluralismo y Constitución: estudios de teoría constitucional de la sociedad abierta. Madrid: Tecnos, 2008b.

Textos clássicos na vida das Constituições. São Paulo: Saraiva, 2016.

HABERMAS, Jürgen. O discurso filosófico da modernidade: doze lições. São Paulo: Martins Fontes, 2002.

. Mudança estrutural da esfera pública. Rio de Janeiro: Tempo Brasileiro, 2003.

HESSE, Konrad. A força normativa da constituição. Tradução de Gilmar Ferreira Mendes. Porto Alegre: Sergio Antonio Fabris Editor, 1991.

MARTINEZ, Vinício; FROCEL, Jéssica et al. Transmutação constitucional na Carta Política. Revista Jus Navigandi, ISSN 1518-4862, Teresina, ano 23, n. 5340, 13 fev. 2018. Disponível em: <https://jus.com.br/artigos/64015>. Acesso em: 4 maio 2018.

STRECK, Lenio Luiz; LIMA, Martonio Mont'Alverne Barreto; OLIVEIRA, Marcelo Andrade Cattoni de. A NOVA PERSPECTIVA DO SUPREMO TRIBUNAL FEDERAL SOBRE O 
CONTROLE DIFUSO: MUTAÇÃO CONSTITUCIONAL E LIMITES DA LEGITIMIDADE DA JURISDIÇÃO CONSTITUCIONAL. Argumenta Journal Law, Jacarezinho - PR, n. 7, p. 45-68, fev. 2013. ISSN 2317-3882. Disponível em: <http://seer.uenp.edu.br/index.php/argumenta/article/view/72/72>. Acesso em: 28 abr. 2018.

Data de Submissão: 10/01/2020

Data de Aceite: 13/03/2020 